\title{
DIAGNOSIS OF CORONAVIRUS BY REAL-TIME PCR IN BROILER FIELDS IN DUHOK GOVERNORATE, KURDISTAN REGION OF IRAQ
}

\author{
Renas Husain Isa*, Jassim Mohammed ABdo** and Yousif Mohammed SAlih Al-Barzinji *** \\ *Dept. of Animal Production, Collage of Agriculture Engineering Sciences, University of Duhok, \\ Kurdistan region-Iraq \\ ** College of Pharmacy, University of Duhok, Kurdistan region-Iraq \\ ${ }^{* * *}$ Dept. of Animal Resources, Collage of Agriculture Engineering Sciences, \\ University of Salahaddin -Erbil-Iraq
}

(Received: December 4, 2019; Accepted for Publication: February 4, 2020)

\begin{abstract}
Avian infectious bronchitis disease is reported as the main problem in the poultry industry in the Kurdistan region of Iraq. This study was performed to diagnose Infectious bronchitis among suspected broiler farms located in Duhok governorate, Northern of Iraq as well as to evaluate the efficiency of RealTime PCR for the detection of the causative virus of this disease. In this study, one hundred and eighty tracheal tissue samples were collected from sixty suspected broiler farms from April 2018 to July 2019. RNA was successfully extracted and used for detection by Real-Time PCR technique using commercial kit targeting $160 \mathrm{bp}$ of $S$ gene which is the conserved region for all avian infectious bronchitis virus strains. Out of sixty suspected farms sixteen $\mathbf{( 2 6 . 6 6 \% )}$ ) farms were positive to the infectious bronchitis virus. This study confirms the presence of avian infectious bronchitis disease in this area by Real-Time PCR. Although a single study was performed to detect this disease by Reverse Transcription Polymerase Chain Reaction in this governorate, this is the first study to use Real-Time PCR in the diagnosis of this disease in this area and it was highly efficient for detection of this virus.
\end{abstract}

KEYWORDS: Real-Time PCR, Coronavirus, IBV, Broiler, Duhok, Iraq.

\section{INTRODUCTION}

$\mathbf{I}$ nfectious bronchitis disease (IB) is one of the most challenging diseases for the poultry industry. Chicken is exposed to IB in all ages (Cavanagh et al., 2002; Britton and Cavanagh, 2007). It leads to massive economic loss in both broiler and layer production worldwide due to the rise and fast distribution of new variants or serotypes (Callison et al., 2001; de Wit et al., 2011). This disease causes $100 \%$ morbidity with 20-30\% mortality (Ignjatovic et al., 2002; Seifi et al., 2010) and sometimes higher due to secondary infections (Ignjatovic and Sapats, 2000).

The etiological agent of this disease is the Infectious bronchitis virus (IBV) which is an envelope, mostly rode shape, positive singlestrand RNA coronavirus belongs to the genus Gamma coronavirus, subfamily Coronavirinae, family Coronaviridae, in the order Nidovirales. Moreover, it can affect many organs of the chicken's body including the upper respiratory tract, genital tract, kidneys, and ovaries. After the incubation period (24-48 hours) the symptoms appear, which include tracheal rales, sneezing, kidney swelling and ovary damage (Samatha, 2017). Due to these, it may lead to loss of weight gain and drop in egg production (Callison et al., 2001). It is transmitted horizontally such as airborn route, direct and indirect contact (contamination and poor biosecurity).

The diagnosis is achieved by several tests based on protein and nucleic acids of the virus (Samatha, 2017). These tests include virus neutralization (VN), agar gel immunodiffusion (AGID), haemagglutination inhibition (HI) and enzyme-linked immunosorbent assays (ELISA) (de Wit, 2000). However, tests that are based on the virus nucleic acid detection are widely used due to their accuracy, reliability, and sensitivity. Reverse Transcription Polymerase Chain Reaction (RT-PCR) and Real-Time Reverse Transcription Polymerase Chain Reaction (RRT- 
PCR) are the main of these tests (Bande et al., 2016).

In recent years, the pathogenicity and distribution of this disease have been studied and recorded in the south and middle of Iraq (Alazawy et al., 2017; Mahmood et al., 2017). Additionally, several studies have been carried out in the Kurdistan region of Iraq either to detect or record the distribution of this disease in this area (AL-Barwary and Goreal, 2012). The new variant has been isolated and sequenced, Sul/01/09, in Sulaimani province with $27 \%-28 \%$ amino acid differences in all vaccine strains used in that area (Mahmood et al., 2011). In Duhok province, a single study on IBV has shown that $41.6 \%$ of suspected samples were positive to IB by ELISA test and $44.4 \%$ were positive by RTPCR (AL-Barwary and Goreal, 2012). Therefore, the aims of this study were to detect the prevalence of IB disease in the broiler farms in this province and to evaluate the Real-Time PCR technique efficiency for the detection of this virus.

\section{MATERIALS AND METHODS \\ 2.1 Sample collection}

A total of one hundred and eighty samples of tracheal tissue were collected from sixty suspected broiler's farms including seven districts (Duhok, Zakho, Amedi, Akre, Shekhan, Bardarash and Sumel) in Duhok governorate located in Kurdistan region of Iraq during April 2018 to July 2019. Depending on the literature (Liu, 2016), five dead or sick birds from each poultry farm with clinical IBV symptoms (Figures 1 and 2) were selected and transferred to the lab for sample collection. Specimens of trachea samples were put in sterile tubes and saved at $-20^{\circ} \mathrm{C}$ until the time of RNA extraction. On the day of collection, complete data from each suspected field were recorded.

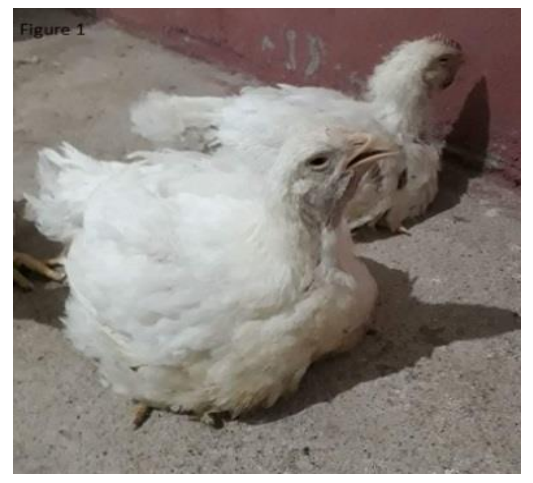

Fig. (1): Broiler chicks with suspected IBV infection showing difficult breathing.

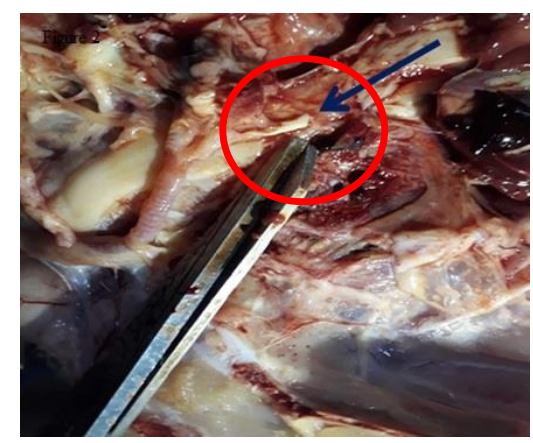

Fig. (2): Post-mortem examination of suspected IBV infection. The arrow shows the presence of a plug in the bifurcation of bronchi.

\subsection{RNA Extraction}

RNA was extracted in Duhok Research Center (DRC) using PowerPrep ${ }^{\mathrm{TM}}$ Viral DNA/RNA Extraction Kit (Kogenebiotech, Seoul, Korea). Three tracheal tissues from each farm were pooled and homogenized by Pestle and mortar. RNA extraction was done according to the procedure given by the manufacturer. Briefly, after grinding $50 \mathrm{mg}$ of sample in $400 \mu \mathrm{l}$ of nuclease-free water, $200 \mu 1$ of the suspension was used for RNA extraction. Later, $500 \mu 1$ of lysis buffer added and incubated for 10 minutes. Then, $700 \mu$ l of binding buffer added before transferring to the spin column. The column was washed twice with $500 \mu 1$ of Wash buffer A and B respectively. Finally, the RNA was eluted in 30-100 $\mu$ l of elution buffer. RNA purity and quantity were checked by NanoDrop 2000/2000 and saved at 20 for downstream applications.

\subsection{Diagnosis of IB virus}

Presence of Viral RNA was diagnosed in Central Public Health Laboratory at Azadi General Hospital, Duhok governorate by using PowerPrep $^{\mathrm{TM}}$ IBV/IBDV Real-Time PCR Kit (kogenebiotech, Soul, Korea) targeting 160 bp of 
the conserved region of $\mathrm{S}$ gene of IBV. The reaction was performed by using Rotor-Gene $\mathrm{Q}^{\mathrm{TM}}$ Thermal Cycler (country). Total of $20 \mu \mathrm{l}$ of reaction volume was made for each sample as well as the negative and positive control, containing $4.2 \mu \mathrm{l}$ of primer/probe mixture, $10 \mu \mathrm{l}$ of 2X RT-PCR reaction buffers, $0.8 \mu$ l of $25 \mathrm{X}$ RT enzyme mix and $5 \mu$ l of template RNA. RealTime PCR reaction conditions were as follows; cDNA synthesis was performed in 1 cycle at 50 ${ }^{\circ} \mathrm{C}$ for 30 minutes, Initial Denaturation was done in 1 cycle at $95^{\circ} \mathrm{C}$ for 10 minutes, Denaturation was done in 40 cycles at $95^{\circ} \mathrm{C}$ for 15 seconds and amplification and fluorescent dye detection was obtained at $60{ }^{\circ} \mathrm{C}$ for 1 minute.

\section{RESULTS}

Based on the clinical symptoms and postmortem examination, all collected samples had suspected IBV symptoms (Figures 1 and 2). However, according to the Real-Time PCR results (Figure 3), out of sixty suspected farms, sixteen cases were positive. Most of the positive samples (9 samples) were from Duhok center (Table 1). While other positive samples were in Amedi: 2, Sumel: 2, Bardarash: 1 and Shekhan: 2 district. Moreover, none of the suspected samples collected from Zakho and Akre were found to be positive to this disease. The percentage of IBV diagnoses in each district within this governorate indicates that more than half of the positive samples to IBV were isolated from Duhok district (Table 1).

Table (1): Percentage of positive IBV in broiler farms from each district within Duhok Governorate using Real-Time PCR.

\begin{tabular}{ccc}
\hline District & Number of positive samples to IBV & Percentage of positive samples to IBV \\
\hline Duhok $^{\mathrm{a}}$ & 9 & $15 \%$ \\
\hline Zakho & 0 & $0 \%$ \\
\hline Sumel & 2 & $3.33 \%$ \\
\hline Akre & 0 & $0 \%$ \\
\hline Bardarash & 1 & $1.66 \%$ \\
\hline Amedi & 2 & $3.33 \%$ \\
\hline Shekhan & 2 & $3.33 \%$ \\
\hline Total & $16 / 60$ & $26.66 \%$ \\
\hline
\end{tabular}

${ }^{\text {a }}$ Center of Duhok Governorate 


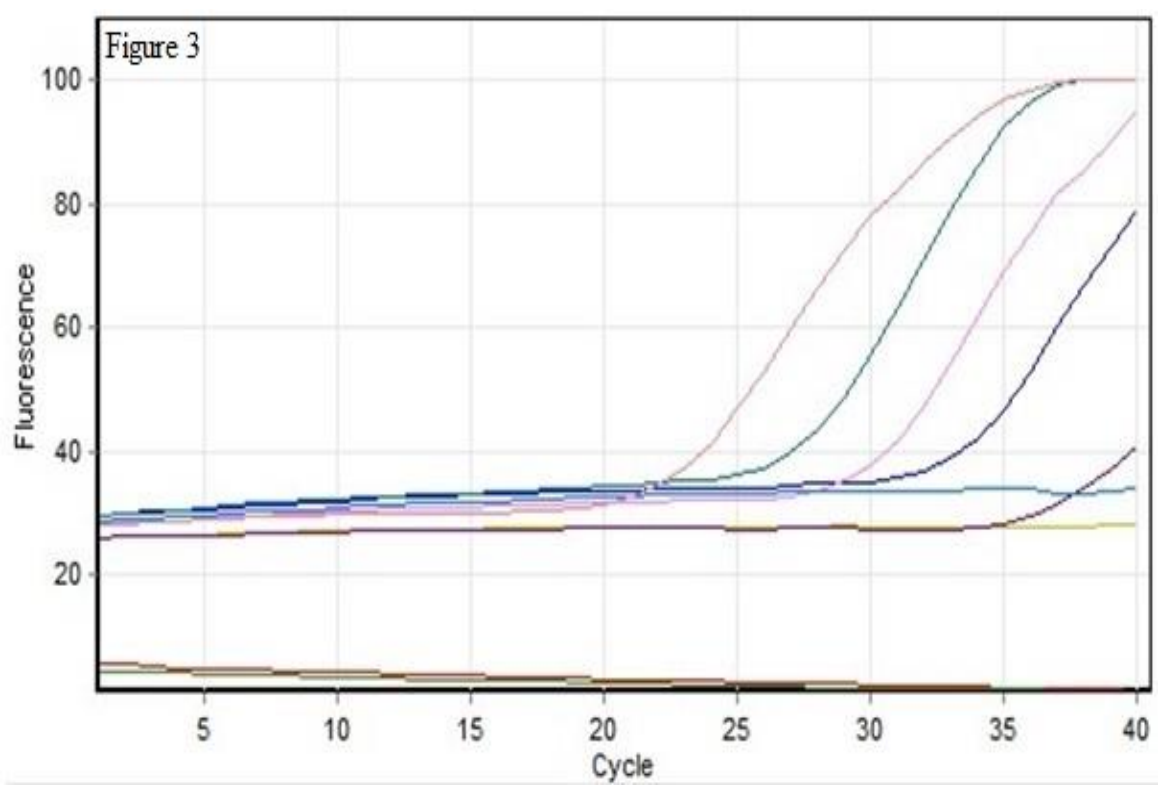

Fig. ( )3: Raw data for some (4 samples) of the positive IBV samples by Real-Time PCR collected from broiler farms located in Duhok governorate, Kurdistan Region of Iraq.

\section{DISCUSSION}

Suspected samples were collected based on the clinical signs of Infectious bronchitis disease such as sneezing, nasal discharge, kidney swelling and plugs in tracheal bifurcation (Samatha, 2017). Most of the samples were collected during the humid season. Bhuiyan et al., (2019) claimed that the disease incidence increase during the winter season due to the favourable nature of $\mathrm{IBv}$ spread within or among poultry houses.

Although suspected samples were collected from sixty broiler farms during the period of more than one year, however, the rate and the distribution of might be more incidences in this area. The reason for hiding the outbreaks is due to the fears of farmers from marketing agencies and government sectors on their farms. According to the local farmers, marketing agencies tent to market their birds with lower prices in case of disease outbreak in any stage of the entire production cycle. Because of this, most of the suspected samples were collected from veterinarian clinics. Real-Time PCR was able to diagnose sixteen samples out of sixty outbreaks. This indicates that this technique is a better diagnostic tool than clinical symptoms and other tests (Bande et al., 2016). In another study that used both ELISA and RT-PCR for the IB, detection concluded that the PCR results are more reliable and accurate than ELISA results (ALBarwary and Goreal, 2008). The reason for the rate of the high difference between this technique and clinical symptoms in diseased broiler may be due to clearance of this disease in the trachea and therefore failure to amplify IBV-genome in the suspected samples (AL-Barwary and Goreal, 2008). An additional point which may complicate the disease detection is that most of the symptoms and lesions related to IB may be obvious in other diseases (Liu, 2016). The differences in disease incidence in different areas within Duhok government may be due to the high density of poultry houses in the specific district compared to others in which density has a direct effect on disease distribution (Mohamed and Ibrahim, 2015). This is due to the nature of disease transmission in which it mainly spread within areas through airborne and/or mechanical transmissions (Cumming, 1970).

The findings of this study indicate that the percentage of disease in Duhok governorate is lower compared to other governorates in the middle and south of Iraq. However, they are higher than the IBV prevalence in Egypt (Mohamed and Ibrahim, 2015). A study by Seger et al., (2016) claimed that $32 \%$ of the collected samples from the middle and south of Iraq were positive to the IB disease. While in another study 
by Alazawy et al., (2017) revealed that $67.5 \%$ of the collected samples were showed positive for the presence of the disease by RT-PCR in the Diyala governorate. Similar results were found in neighbor countries, in Iran, $42.8 \%$ of the results were positive to IB by RT-PCR (Seyfi Abad Shapouri et al., 2004). In Jordan, Roussan et al., (2009) found $58.8 \%$ positive samples from the suspected outbreak.

Most of the vaccines in markets are belong to live attenuated Massachusetts types. Genotyping the local isolates will confirm the best vaccine or vaccination programs against this disease.

\section{CONCLUSION}

The results of this study showed that 16 (26.6\%) out of 60 of collected suspected samples were positive by Real-Time PCR. It is clear that this disease is distributed throughout the governorate. Besides that a single study in this governorate was performed using RT-PCR, this is the first study to use the Real-Time PCR technique in Duhok governorate. This study claims that Real-Time PCR is a fast, reliable and accurate technique for diagnosis of this disease compared to clinical and/or other tests.

\section{ACKNOWLEDGMENT}

The author thanks everyone helped in performing this research. Great thanks to Duhok Research Center (DRC) and its staff. Special thanks to Central Public Health Laboratory at Azadi general hospital, Duhok governorate. The authors appreciate the effort of the private veterinarian clinic in the area, especially the New Vet clinic (Mr. Merkhan Mahdi Mustafa).

\section{REFERENCES}

Alazawy, A. K. S., Abdulhussain, S. R., Nasser, A. T., Albaldawy, A. A. A., Bande, F., and Jameel, G. H. (2017). Serological survey and molecular detection of infectious bronchitis virus in broiler chickens in Diyala province, Iraq. International Journal of Poultry Science, 16, 88-92

AL-Barwary, D. A. M., and Goreal, A. A. (2012). Diagnosis of infectious bronchitis disease in broiler chickens by serological test (ELISA) and RT-PCR in Duhok. International Journal of Animal and Veterinary Advances, 4, 71-75.

Bande, F., Arshad, S. S., Omar, A. R., Bejo, M. H., Abubakar, M. S., and Abba, Y. (2016). Pathogenesis and diagnostic approaches of avian infectious bronchitis. Advance in Virology, 2016.

Bhuiyan, Z. A., Ali, Moula, M. Z., Giasuddin, M. M., M., \& Khan, Z. U. M. (2019). Prevalence and molecular characterization of infectious bronchitis virus isolated from chicken in Bangladesh. Veterinary world, 12, 909-915.

Bhuiyan, Z. A., Ali, M. Z., Moula, M. M., Giasuddin, M., \& Khan, Z. U. M. (2019). Prevalence and molecular characterization of infectious bronchitis virus isolated from chicken in Bangladesh. Veterinary world, 12, 909-915.

Britton, P., and Cavanagh, D. (2007). Avian Coronavirus diseases and infectious bronchitis vaccine development. In: Coronaviruses: Molecular and Cellular Biology. Thiel V., ed. Caister Academic Press, Norfolk, UK, 161181.

Callison, S. A., Jackwood, M. W., and Hilt, D. A. (2001). Molecular characterization of infectious bronchitis virus isolates foreign to the United States and comparison with United States isolates. Avian Diseases, 45, 492-499.

Cavanagh, D., Mawditt, K., Welchman, D. D. B., Britton, P., and Gough, R. E. (2002). Coronaviruses from pheasants (Phasianus colchicus) are genetically closely related to coronaviruses of domestic fowl (infectious bronchitis virus) and turkeys. Avian Pathology, 31, 81-93.

Cumming, R. B. (1970). Studies on Australian InfectiousBronchitis Virus. IBV. Apparent farm to farm airborne transmission of infectious bronchitis virus. Avian Diseases, 14: 191-195.

de Wit, J. J. (2000). Detection of infectious bronchitis virus. Avian Pathology, 29, 71-93.

de Wit, J. J., Cook, J. K., and Van Der Heijden, H. M. (2011). Infectious bronchitis virus variants: a review of the history, current situation and control measures. Avian Pathology, 40, 223235. 
Ignjatovic, J., and Sapats, S. (2000). Avian infectious bronchitis virus. Revue Scientifique et Technique-Office International des Epizooties, 19, 493-501.

Ignjatovic, J., Ashton, D. F., Reece, R., Scott, P., and Hooper, P. (2002). Pathogenicity of Australian strains of avian infectious bronchitis virus. Journal of Comparative Pathology, 126, 115-123.

Liu, D. (2016). Molecular detection of animal viral pathogens. CRC Press.

Mahmood, A., Zahid, A., and Al-Khafaji, Z. (2017). In Silico Characterization of Infectious Bronchitis Coronavirus (Qx Strain) Circulating in Iraq. International Research Journal of Pharmaceutical Sciences, 7, 1-18.

Mahmood, Z. H., Sleman R. R., and Uthman, A. U. (2011). Isolation and molecular characterization of Sul/01/09 avian infectious bronchitis virus, indicates the emergence of a new genotype in the Middle East. Veterinary Microbiology, 150, 21-27.

Roussan, D. A., Khawaldeh, G. Y., and Shaheen, I. A. (2009). Infectious bronchitis virus in Jordanian chickens: seroprevalence and detection. The Canadian Veterinary Journal, 50, 77-80.

Samatha, K. (2017). Isolation and characterization of infectious bronchitis virus. M.Sc. thesis, P.V.

NARSIMHA RAO TELANGANA

VETERINARY UNIVERSITY,
RAJENDRANAGAR, HYDERABAD-30.

Seger, W., GhalyanchiLangeroudi, A., Karimi, V., Madadgar, O., Marandi, M. V., and Hashemzadeh, M. (2016). Genotyping of infectious bronchitis viruses from broiler farms in Iraq during 2014-2015. Archives of virology, 161, 1229-1237.

Seifi, S., Asasi, K., and Mohammadi, A. (2010). Natural co-infection caused by avian influenza H9 subtype and infectious bronchitis viruses in broiler chicken farms. Veterinarski Arhiv, 80, 269-281.

Seyfi Abad Shapouri, MR., Mayahi, M., Assasi, K., and Charkhkar, S. (2004). A survey of the prevalence of infectious bronchitis virus type 4/91 in Iran. Acta Veterinaria Hungarica, 52, 163-166. 